\title{
Review
}

Complications

Diabetes Metab J 2019;43:733-743

https://doi.org/10.4093/dmj.2019.0177

pISSN 2233-6079 · eISSN 2233-6087

DIABET\&S \& METABOLISM JOURNAL

\section{Diabetes and Cancer: Cancer Should Be Screened in Routine Diabetes Assessment}

\author{
Sunghwan Suh ${ }^{1}$, Kwang-Won Kim ${ }^{2}$ \\ ${ }^{1}$ Department of Internal Medicine, Dong-A University College of Medicine, Busan, \\ ${ }^{2}$ Department of Internal Medicine, Gachon University Gil Medical Center, Gachon University College of Medicine, Incheon, Korea
}

Cancer incidence appears to be increased in both type 1 and type 2 diabetes mellitus (DM). DM represents a risk factor for cancer, particularly hepatocellular, hepatobiliary, pancreas, breast, ovarian, endometrial, and gastrointestinal cancers. In addition, there is evidence showing that DM is associated with increased cancer mortality. Common risk factors such as age, obesity, physical inactivity and smoking may contribute to increased cancer risk in patients with DM. Although the mechanistic process that may link diabetes to cancer is not completely understood yet, biological mechanisms linking DM and cancer are hyperglycemia, hyperinsulinemia, increased bioactivity of insulin-like growth factor 1, oxidative stress, dysregulations of sex hormones, and chronic inflammation. However, cancer screening rate is significantly lower in people with DM than that in people without diabetes. Evidence from previous studies suggests that some medications used to treat DM are associated with either increased or reduced risk of cancer. However, there is no strong evidence supporting the association between the use of anti-hyperglycemic medication and specific cancer. In conclusion, all patients with DM should be undergo recommended age- and sex appropriate cancer screenings to promote primary prevention and early detection. Furthermore, cancer should be screened in routine diabetes assessment.

Keywords: Diabetes mellitus; Mass screening; Neoplasms

\section{INTRODUCTION}

People with diabetes mellitus (DM) have an increased risk of developing a number of serious life-threatening health problems resulting in higher medical care costs, reduced quality of life and increased mortality [1]. The global prevalence of diabetes and impaired glucose tolerance in adults has been increasing over recent decades [2]. This trend has been accompanied by increasing rates of some cancers, leading to a hypothesis that there might be a potential direct relationship between DM and cancer [3]. Cancer is a major life-threatening disease worldwide. The global burden of cancer is expected to grow rapidly due to aging population [4]. In Korea, cancer has been the leading causes of death [5]. It is expected to become more common due to aging and westernized lifestyles [6].
Moreover, malignant neoplasm is the most common cause of death in patients with type 2 diabetes mellitus (T2DM) in Korea [7]. This increased risk of cancer deaths in people with diabetes is also shown in other countries [8]. A link between DM and cancer has been noted for at least 100 years [9]. If causal, these associations might be of great importance for public health given the substantial global burden of these diseases [2]. However, some claimed associations could also be caused by biases in the literature, particularly selective reporting biases that favor the publication of significant associations and cause either false positives or inflated estimates of association [10]. In addition, epidemiologic evidence linking antidiabetic drugs with cancer risk has been suspected during the last several years [11,12].

We have previously published a review article about the
Corresponding author: Kwang-Won Kim (iD https://orcid.org/0000-0003-1046-117X Department of Internal Medicine, Gachon University Gil Medical Center, Gachon University College of Medicine, 21 Namdong-daero 774beon-gil, Namdong-gu, Incheon 21565, Korea

E-mail:kwkim@gilhospital.com
This is an Open Access article distributed under the terms of the Creative Commons Attribution Non-Commercial License (http://creativecommons.org/licenses/by-nc/4.0/) which permits unrestricted non-commercial use, distribution, and reproduction in any medium, provided the original work is properly cited. 
causal relation between diabetes and cancer in 2011 [13]. In the present review, we updated with the most recent evidences regarding this issue and reinforced the issue of pharmacologic therapy of DM and cancer risk with suggestions.

\section{INCREASED CANCER INCIDENCE IN PATIENTS WITH DIABETES}

Cancer incidence appears to be increased in both type 1 diabetes mellitus (T1DM) and T2DM [14]. A comprehensive metaanalysis regarding T2DM and risk of developing cancer and mortality has shown that the presence of diabetes is associated with a $10 \%$ increase of the relative risk (RR) to develop cancer (RR, 1.10; 95\% confidence interval [CI], 1.04 to 1.17) as shown in Table 1 [10]. In that analysis, evidence was substantiated for associations between T2DM and risk of developing hepatocellular, hepatobiliary, pancreas, breast, ovarian, endometrial and gastrointestinal cancers as shown in Table 1. The RR of incidence of all cancer types for Asian men was significantly higher than that for non-Asian men [15]. Since more than $90 \%$ of patients with diabetes who are affected by T2DM generally belong to an age group particularly affected by cancer, the association between T2DM and cancer is stronger compared to that between T1DM and cancer [14]. However, significant higher incidence of cancer has also been demonstrated in subjects with T1DM, particularly evident in liver, pancreas, kidney, endometrium, and ovary cancers [16]. Moreover, prediabetes is also associated with an increased risk of cancer, especially liver, endometrial, stomach and colorectal cancers [17].

\section{INCREASED CANCER MORTALITY IN PATIENTS WITH DIABETES}

Interestingly, DM could represent an independent risk factor for higher cancer-related mortality, particularly evident for colon, pancreas, and breast cancers in women and for liver and intestine cancers in men [18]. However, since DM is associated with higher mortality than the general population $[19,20]$, it is not completely understood whether the higher mortality of patients with diabetes associated with cancer is independent of this factor. Although the relationship between diabetes and cancer-specific mortality is inconsistent [21,22], there is emerging evidence that T2DM is associated with an increased risk of death from cancer. A previous meta-analysis has estimated that diabetes is associated with $41 \%$ increased risk of death
Table 1. Random effects estimates with 95\% confidence and prediction intervals from 27 meta-analyses of type 2 diabetes mellitus and incidence of cancer or mortality

\begin{tabular}{|c|c|c|}
\hline Cancer origins & No. of cases & $\begin{array}{l}\text { Random effects } \\
(95 \% \mathrm{CI})\end{array}$ \\
\hline Total cancer incidence & 38,010 & $1.10(1.04-1.17)$ \\
\hline Total cancer mortality & 11,386 & $1.16(1.04-1.30)$ \\
\hline Prostate cancer incidence & 135,970 & $0.91(0.82-1.01)$ \\
\hline Thyroid cancer incidence & 1,230 & $1.16(0.97-1.39)$ \\
\hline Lung cancer incidence & 207,454 & $1.03(0.94-1.13)$ \\
\hline Gastric cancer incidence & 15,970 & $1.09(0.98-1.22)$ \\
\hline Gastric cancer mortality & 2,447 & $1.29(1.04-1.59)$ \\
\hline Colorectal cancer incidence & 61,690 & $1.27(1.21-1.34)$ \\
\hline Colorectal cancer mortality & 4,394 & $1.20(1.03-1.40)$ \\
\hline Hepatocellular carcinoma incidence & 33,765 & $2.31(1.87-2.84)$ \\
\hline Hepatocellular carcinoma mortality & 292 & $2.43(1.67-3.55)$ \\
\hline Breast cancer incidence & 30,859 & $1.20(1.12-1.28)$ \\
\hline Breast cancer mortality & 4,442 & $1.24(0.95-1.62)$ \\
\hline Endometrial cancer incidence & 8,174 & $1.97(1.71-2.27)$ \\
\hline Endometrial cancer mortality & 103 & $1.23(0.78-1.93)$ \\
\hline Ovarian cancer incidence & 7,651 & $1.17(1.02-1.34)$ \\
\hline Kidney cancer incidence & 12,980 & $1.38(1.10-1.72)$ \\
\hline Kidney cancer mortality & 2,646 & $1.16(1.01-1.33)$ \\
\hline Esophageal cancer incidence & 3,001 & $1.30(1.12-1.50)$ \\
\hline Bladder cancer incidence & 50,676 & $1.35(1.17-1.56)$ \\
\hline Gallbladder cancer incidence & 1,821 & $1.52(1.26-1.84)$ \\
\hline $\begin{array}{l}\text { Extrahepatic cholangiocarcinoma } \\
\text { incidence }\end{array}$ & 2,431 & $1.63(1.29-2.05)$ \\
\hline Pancreatic cancer incidence & 52,445 & $1.95(1.66-2.28)$ \\
\hline $\begin{array}{l}\text { Intrahepatic cholangiocarcinoma } \\
\text { incidence }\end{array}$ & 3,152 & $1.97(1.57-2.46)$ \\
\hline Multiple myeloma incidence & 3,051 & $1.27(0.98-1.64)$ \\
\hline $\begin{array}{l}\text { Non-Hodgkin's lymphoma } \\
\text { incidence }\end{array}$ & 12,353 & $1.27(1.09-1.48)$ \\
\hline Leukemia incidence & 4,156 & $1.28(1.05-1.57)$ \\
\hline
\end{tabular}

Modified from Tsilidis et al. [10].

CI, confidence interval.

from any cancer [23]. More recent meta-analysis has also found the risk of cancer mortality in patients with T2DM is increased 16\% [10] as shown in Table 1. However, most studies on the association between diabetes and cancer risk have been conducted in Western populations [10]. In a recent analysis of 19 Asian cohorts including more than 771,000 participants fol- 
lowed for up to 21 years, diabetes was associated with a $26 \%$ increase in the risk of death from any cancer [24] in line with Western studies. T1DM is also associated with an increased risk of overall and site specific cancer incidence and mortality [25]. Specifically, DM is related to an increased risk of death from colorectal cancer, liver cancer, bile duct cancer, gallbladder cancer, pancreatic cancer, breast cancer, endometrial cancer, ovarian cancer, prostate cancer, kidney cancer, thyroid cancer and lymphoma [24]. Another study has also found that cancer patients with DM are frequently treated less aggressively and have a worse prognosis compared to those without diabetes [26]. The association of DM with specific cancers suggests a need for better control (prevention, detection, and management) of the growing epidemic of DM in order to reduce cancer mortality. These findings indicate a potential need for appropriate cancer screening among individuals with DM. However, further research is needed to determine if more stringent management of insulin resistance and hyperglycemia in patients with cancer can improve their response to oncology treatments and overall survival [11].

\section{COMMON RISK FACTORS FOR BOTH DIABETES MELLITUS AND CANCER}

$\mathrm{DM}$ and cancer represent common health concerns. They often coexist in the same individual. Overall, $8 \%$ to $18 \%$ of individuals suffering from cancer also have diabetes. The prevalence of cancer in patients with DM varies according to tumor site [27]. The association may result from shared risk factors between T2DM and cancer (older age, obesity, physical inactivity, and smoking) as shown in Table 2. It may also be due to diabetes-related factors, such as underlying disease physiology and diabetes treatments [28,29], although evidence for these links is scarce. A recent study using a large database suggested that increases in DM and body mass index (BMI) worldwide could lead to a substantial increase in cancer burden in future decades [29]. Therefore, population-based strategies to prevent DM and high BMI have great potential impact because these two diseases have overlapping risk factors, comorbidities, and shared sequelae, such as cancer [30]. Future efforts should focus on identifying the most effective clinical interventions to prevent the development of DM and obesity in at-risk groups to halt and reverse the rise in DM. In addition, global efforts and clinical guidance should reflect the importance of cancer as a sequela of both DM and obesity. Control measures should
Table 2. Common risk factors and biological mechanisms linking diabetes and cancer

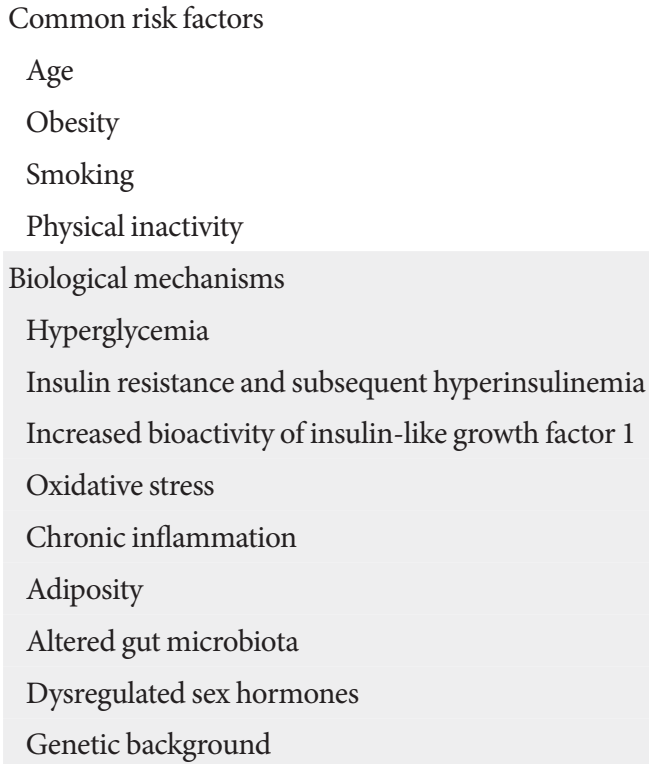

also be integrated into clinical guidelines to identify opportunities to reduce morbidity in this group of patients [29].

\section{POSSIBLE MECHANISMS UNDERLYING DIABETES MELLITUS AND CANCER}

Although the mechanistic process that may link diabetes to cancer is not completely understood yet, several experimental observations have suggested how multiple risk factors involving proliferation and apoptosis pathways may be in common between T2DM and cancer [11]. The major risk factors were hyperglycemia [31,32], hyperinsulinemia [31], increased bioactivity of insulin-like growth factor 1 (IGF-1) [33], oxidative stress [34], dysregulations of sex hormones, and chronic inflammation $[28,35]$ as shown in Table 3. Supraphysiological concentrations of insulin and glycemia to which body tissues are exposed represent a potent growth factor and energy source, respectively. They are essential for neoplastic transformation and cancer progression [34]. Insulin resistance, subsequent hyperinsulinemia (i.e., insulin can promote mitogenic effect on pancreatic cells in vitro), and hyperglycemia have been hypothesized as the biological mechanism that link T2DM to pancreatic cancer incidence [31]. Hyperinsulinemia also has an indirect effect on endometrial, breast and ovarian tissues by increasing endogenous estrogen and androgen levels 
Table 3. Potential risks of anti-hyperglycemic medications and cancer

\begin{tabular}{llll}
\hline Drug class & \multicolumn{1}{c}{ Clinical evidence on cancer } & Reference \\
\hline Sodium glucose cotransporter 2 inhibitors & Safe with currently available data, further studies are needed & {$[46,47]$} & {$[14,48-53]$} \\
Incretin-based drugs & Safe with currently available data, further studies are needed & {$[11,12,54-63]$} \\
Thiazolidinediones & Neutral except bladder cancer risk & {$[11,14,65-67]$} \\
Sulfonylureas & Neutral & Neutral maybe beneficial & {$[64,68-71]$} \\
Metformin & Neutral & {$[11,12,33,72-77]$} \\
Insulin analogue & &
\end{tabular}

as well as decreasing plasma levels of sex hormones binding globulin [36]. Moreover, hyperglycemia is responsible for induction of oxidative stress and DNA damage, which may trigger the first phases of tumorigenesis [37,38]. Epidemiologic evidence supports the role of insulin and the IGF pathway in cancer incidence. Some cohort studies have described an association between increased levels of IGF-1 and risk of cancer [33]. Furthermore, patients affected by acromegaly, a disorder characterized by excess of growth hormone and IGF-1, have been shown to have increased risks of several types of cancer [39].

Interestingly, a recent review showed that adiposity and obesity were associated with several cancers [40]. The excess of weight was associated with increased cancer risk probably by biological pathways that involve hormonal control, cellular proliferation, and inflammation [41]. Similar mechanisms have been hypothesized for the association of T2DM and cancer. In the relationship between T2DM and cancer, obesity can act as an important confounder or as an effect modifier. A previous study estimated that about $3.6 \%$ of all cancer cases in 2012 were attributable to obesity [42]. In a recent population study, a substantial number of cancer cases were attributable to diabetes and obesity [29].

The most convincing pathophysiological mechanisms implicated in the association between T2DM with cancer have been proposed for colorectal cancers [3]. In particular, the T2DM microenvironment, represented by advanced glycation endproducts, chronic local inflammation, hyperlipidemia, extracellular matrix disorders and altered microbiota could predispose the development of colorectal cancer [3]. The plausibility of these mechanisms was strengthened by a meta-analysis [43] that showed a strong association of markers of glucose metabolism (including fasting glucose, fasting insulin, homeostasis model of risk assessment-insulin resistance, glycated hemoglobin, and C-peptide) with colorectal cancer. Furthermore, a meta-analysis by Yu et al. [44] has suggested that T2DM plays a role also in developing colorectal adenomas, a well-known precursor lesions lesion of colon cancer, demonstrating a role in all the natural history of disease in line with our previous report [45].

Further studies are needed to fully identify mechanisms involved in the reciprocal interaction between diabetes and cancer to prevent additional burden and promote targeted clinical and social prevention strategies. Researchers across diabetes and cancer communities must continue to collaborate, design trials, and explore new and existing databases, especially when outcomes are rare. In addition, editors and readers of the journal must be aware of methodological pitfalls of each study before interpreting its results.

\section{ANTI-HYPERGLYCEMIC MEDICATION AND CANCER}

Evidence from both observational and experimental studies suggests that some medications used to treat DM are associated with either increased or reduced risk of cancer [14]. As a result, several anti-hyperglycemic drugs introduced over the last decade have been under surveillance by regulatory agencies for possible increase in tumor incidence. In general, anti-diabetes therapies such as sulfonylureas (SUs) and exogenous insulin associated with hyperinsulinemia have been shown to increase cancer risk while treatments associated with amelioration of insulin resistance such as metformin may reduce this risk $[11,12]$. However, awareness of methodological shortcomings such as prevalent-user bias, detection bias, reverse causality, time-related bias, and residual confounding afflicting most of these previous studies is increasing [14]. As a result, there is currently no definitive evidence for a carcinogenic effect of any anti-diabetic therapeutics. However, given the novelty and benefit of some of these agents and conflicting study results, future well-designed prospective trials are needed to further elu- 
cidate their neoplastic or anti-neoplastic effects. Even if the evidence for specific drugs affecting cancer risk is still incomplete, anti-diabetes therapy should not be recognized as a contributing risk factor. Therefore, cancer risk should not be a major factor when choosing between available diabetes therapies for an average patient. Yet, for a selected sub-group of patients exhibiting a history or risk of specific types of cancer, the choice of antidiabetic drug may require more meticulous evaluation.

\section{Sodium glucose cotransporter 2 inhibitors}

Sodium glucose cotransporter 2 (SGLT2) inhibitors can lower blood glucose by impairing its renal resorption, thus increasing its urinary excretion. While this strategy results in reduction of hyperglycemia, epithelial cells in nephron segments downstream the renal proximal tubule are exposed to constant glycosuria whose effect remains to be elucidated. A meta-analysis of 46 randomized controlled studies indicated that SGLT2 inhibitors did not significant increase the risk of overall cancer [46]. Accordingly, a post hoc pooled analysis of clinical trials with dapagliflozin showed no significant difference in risk of any type of cancer, including bladder cancer, between treatment and placebo groups [47]. As SGLT2 inhibitors are relatively new in clinical practice, their effects on cancer incidence or mortality cannot be easily assessed in short-term trials or in those with follow-up for a few years. These issues should be further delineated in large-scale, controlled studies with longer duration of follow-up.

\section{Incretin-based drugs}

Incretin-based therapy is broadly and increasingly used in T2DM, although some concerns about its effects on carcinogenesis of the pancreas and thyroid have been raised by both preclinical and observational studies $[48,49]$. These new class of drugs went through large-scale clinical trials. There is no evidence that glucagon-like peptide-1 (GLP-1) receptor agonist [50] or dipeptidyl peptidase-4 inhibitors [51] can increase the risk of pancreatic cancer. A meta-analysis of six cardiovascular outcomes trials (CVOTs) has found that the risk of pancreatic cancer in patients on incretin-based is similar to that in patients on other therapies [52]. Concerns about medullary thyroid cancer are due to the observation that GLP-1 receptors are expressed in all thyroid tissues, especially in settings of C-cell hyperplasia and medullary thyroid cancer. Incretin therapy resulted in increased calcitonin levels in rodents but not in primates and humans, who have fewer C-cells and GLP-1 recep- tor levels [53]. In recent CVOTs, cancer rates did not differ between incretin users and controls. Specifically no thyroid cancers were reported $[14,49]$. As these incretin-based agents are increasingly used in the treatment of T2DM, their potential antineoplastic and procarcinogenic effects must be further addressed in future clinical studies.

\section{Thiazolidinediones}

Thiazolidinediones (TZDs) are commonly used as insulinsensitizers and glucose and lipid-lowering agents in T2DM [54]. In a meta-analysis of randomized trials, TZD was associated with a significantly lower risk of colon cancer and a significant reduction in breast cancer $[12,55]$. However, other clinical studies have failed to corroborate their antineoplastic effect in colorectal [56] and breast cancer $[57,58]$. Until now, the role of TZDs in cancer treatment and prevention is uncertain [11].

On the contrary, there are concerns regarding increased incidence of bladder cancer associated with pioglitazone use. The prospective pioglitazone clinical trial in macrovascular events (PROactive Study) was the first to draw attention to the association of bladder cancer with pioglitazone use in humans [59]. Some observational studies have suggested a possible link between the two. However, there is no association between bladder cancer and pioglitazone in randomized controlled trials (RCTs) [60]. Jin et al. [61] could not find an association between ever use of pioglitazone and bladder cancer in a prevalent case-control analysis nested within a Korean cohort. A prospective study from Kaiser Permanente database has found that pioglitazone use is not associated with increased risk of bladder cancer [62]. Although there is a possible association between bladder cancer and pioglitazone, the causality is not definitely proven considering results from the most recent meta-analysis [63]. These new studies suggest that the association of bladder cancer with pioglitazone might be due to ascertainment bias [64]. Further confirmatory studies are required to answer this question. To be safe, European Medicines Agency advises that risk factors for bladder cancer should be assessed and that pioglitazone should be avoided in patients with a history of bladder cancer, affected by this disease, or with uninvestigated macrohematuria before prescription. Despite concerns regarding bladder cancer, we should remember that TZD has an undoubtable cardiovascular benefit [60].

\section{Sulfonylureas}

SUs are among the oldest drug classes available for the treat- 
ment of T2DM. SUs act as insulin secretagogues. They are still extensively used in T2DM treatment [54]. A primary data meta-analysis has analyzed 24 metformin studies and 18 SU studies investigating the correlation between antidiabetic drugs and cancer incidence [65]. In this analysis, increased cancer risk emerged only in cohort studies regarding SUs, whereas case-control and RCTs failed to confirm this finding [65]. Accordingly, a retrospective cohort study using data from the registry of the surveillance, epidemiology, and end results (SEER) program of the National Cancer Institute showed that patients on SUs were at higher risk of breast cancer death (hazard ratio, 1.49; 95\% CI, 1.00 to 2.23) [66]. However, most of these previous studies bore the burden of time-related biases. When these biases were eliminated, no increased risk of malignancies was detected [14]. Moreover, no evidence of any effect of glipizide or glimepiride, so-called 2nd generation SUs, on tumor growth has been reported [67]. Although SUs have been in clinical use for many years, their associations with cancer remains uncertain [11]. Further and more statistically accurate epidemiological studies are thus required for a better understanding of the link between SUs and cancer.

\section{Metformin}

Metformin is the first-line T2DM treatment and reduces hyperglycemia by primarily reducing hepatic gluconeogenesis with subsequent lowering of insulin requirements [54]. A large meta-analysis has shown that metformin may reduce cancer risk and improve the prognosis and survival of cancer patients [68]. These results are complemented by studies in cancer cell lines in vitro and in animal models, in which metformin appears to reduce proliferation of cancer cells [69]. The mechanism underlying protective effects of metformin against cancer initiation has been linked to AMP-activated protein kinase (AMPK) activation, mammalian target of rapamycin (mTOR) inhibition, and concomitant reduction of insulin levels [70]. To date, most in vitro studies and animal models that demonstrate antineoplastic effects of metformin involve doses that are substantially higher than those indicated for treatment of T2DM [71]. Therefore, it is unclear if metformin can exert direct effects on tumors in patients. The possible role of metformin as an antineoplastic agent is being extensively studied and several novel anti-cancer mechanisms have been demonstrated [64]. Although repurposing drugs with excellent safety profiles is an appealing strategy for cancer prevention and treatment in an adjuvant setting, there is no substitute for well-executed, large
RCTs to define efficacy and determine populations that are most likely to benefit from metformin prescription [69].

\section{Insulin analogue}

Several insulin analogues have been developed aiming at restoring the physiological insulin kinetics and control blood glucose excursions [54]. Studies in cell models comparing the activity of insulin analogues to that of native insulin and exploring insulin receptor and IGF-1 receptor signaling have indicated that minor differences may exist between insulin and short-acting analogues. However, there has been claim that long-acting analogues may activate mitogenic pathways more than insulin, thus increasing cell proliferation [72]. Potential mechanisms by which administration of insulin or insulin analogues might affect neoplastic disease include several aspects [33]: (1) insulin glargine has much higher affinity to the IGF-1 receptor and higher mitogenic potency, than human insulin or other analogues; (2) long-acting analogues have a slower dissociation rate than native insulin (about 1.5 to 3 times longer); and (3) the growth-promoting effect of insulin analogues on malignant cells due to its mitogenic effects. Indeed, despite these therapies are associated with metabolic benefit, some retrospective studies have highlighted an increased risk of cancer within the first years after starting insulin treatment, particularly breast cancer after insulin glargine administration [11, 12]. However, these observational studies had design limitations, making it impossible to draw firm conclusions [73]. In addition, both the outcome reduction with initial glargine intervention (ORIGIN) trial [74] and the ORIGIN and legacy effects (ORIGINALE) study [75] reported neutral effects of insulin glargine on cancers. These large long-term data seemed definitive, leading some commentators to suggest closure on this topic [64]. In addition, a recent multi-country cancer risk and insulin analogues (CARING) project which included 250,000 patients noted no increased risk for development of any cancers with insulin glargine or insulin detemir compared to human insulin with a follow-up exceeding 5 years [76]. Furthermore, it has been more recently clarified that, following in vivo administration in humans, insulin glargine is rapidly and almost completely transformed into active metabolites that have the same mitogenic properties as human insulin [77]. In summary, although in vitro studies have raised concerns regarding mitogenic effects of insulin analogues, particularly glargine, the relevance of these in vitro studies to humans is questionable. To date, there is no strong evidence supporting the asso- 
ciation between the use of insulin analogues and cancer [11].

\section{CANCER SCREENING IN PEOPLE WITH DIABETES}

We are now aware that patients with DM are at increased risk of several common cancer types compared to the general population. However, this does not translate into a need for more intensive cancer screening in patients with DM. The American diabetes association guidelines recommends that patients with diabetes should be encouraged to undergo recommended ageand sex appropriate cancer screenings and reduce their modifiable cancer risk factors (obesity, physical inactivity, and smoking) [78]. Special attention is needed for those with new onset of atypical diabetes (elderly, having lower premorbid BMI, weight loss and no family history of diabetes) who need screening of pancreatic cancer as we have previously recommended [79]. In Korea, the national cancer screening program was implemented in 1999 by the Korean government as an organized cancer screening program. Opportunistic screenings are also provided depending on individuals' needs [80]. However, in a Korean study using nationwide survey and health examination data, cancer screening rate (both lifetime screening rate and recommended screening rate for gastric, breast, and cervical cancers) was significantly lower in people with DM than that in people without diabetes [81]. Moreover, lower cancer screening rates in older people with DM than in people without diabetes in the same age group, especially regarding recommended screenings for gastric and breast cancer, were observed in that study [81]. Previous studies conducted in Western countries have consistently shown lower cancer screening rates in people with DM $[82,83]$, similar to the Korean study. Therefore, advising patients with DM to get these health examinations is of upmost importance. In the future, continuous public health efforts should emphasize the importance of long-term preventive care, including cancer screening, for high-risk populations such as individuals with DM. In addition, future research should focus on cancer screening rate by type and duration of DM and medication used.

\section{CONCLUSIONS}

With escalating prevalence of DM, risks of cancer and cancerrelated mortality are significantly increased, causing great concern internationally. Diabetes represents a risk factor for can- cer, particularly hepatocellular, hepatobiliary, pancreas, breast, ovarian, endometrial, and gastrointestinal cancers. The association between DM and cancer has important implications for reiterating the importance of controlling lifestyle factors. Thus, cancer should be screened in routine diabetes assessment.

\section{CONFLICTS OF INTEREST}

No potential conflict of interest relevant to this article was reported.

\section{ORCID}

Sunghwan Suh https://orcid.org/0000-0001-6865-966X

Kwang-Won Kim https://orcid.org/0000-0003-1046-117X

\section{ACKNOWLEDGMENTS}

This work was supported by the research fund of Dong-A University, Busan, Republic of Korea.

\section{REFERENCES}

1. GBD 2017 Disease and Injury Incidence and Prevalence Collaborators. Global, regional, and national incidence, prevalence, and years lived with disability for 354 diseases and injuries for 195 countries and territories, 1990-2017: a systematic analysis for the Global Burden of Disease Study 2017. Lancet 2018;392:1789-858.

2. Cho NH, Shaw JE, Karuranga S, Huang Y, da Rocha Fernandes JD, Ohlrogge AW, Malanda B. IDF Diabetes Atlas: global estimates of diabetes prevalence for 2017 and projections for 2045. Diabetes Res Clin Pract 2018;138:271-81.

3. Sacerdote C, Ricceri F. Epidemiological dimensions of the association between type 2 diabetes and cancer: a review of observational studies. Diabetes Res Clin Pract 2018;143:369-77.

4. GBD 2017 Causes of Death Collaborators. Global, regional, and national age-sex-specific mortality for 282 causes of death in 195 countries and territories, 1980-2017: a systematic analysis for the Global Burden of Disease Study 2017. Lancet 2018; 392:1736-88.

5. Lim D, Ha M, Song I. Trends in major cancer mortality in Korea, 1983-2012, with a joinpoint analysis. Cancer Epidemiol 2015;39:939-46.

6. Jung KW, Won YJ, Kong HJ, Lee ES; Community of Popula- 
tion-Based Regional Cancer Registries. Cancer statistics in Korea: incidence, mortality, survival, and prevalence in 2015. Cancer Res Treat 2018;50:303-16.

7. Kang YM, Kim YJ, Park JY, Lee WJ, Jung CH. Mortality and causes of death in a national sample of type 2 diabetic patients in Korea from 2002 to 2013. Cardiovasc Diabetol 2016;15:131.

8. Gordon-Dseagu VL, Shelton N, Mindell J. Diabetes mellitus and mortality from all-causes, cancer, cardiovascular and respiratory disease: evidence from the Health Survey for England and Scottish Health Survey cohorts. J Diabetes Complications 2014;28:791-7.

9. Greenwood M, Wood F. The relation between the cancer and diabetes death-rates. J Hyg (Lond) 1914;14:83-118.

10. Tsilidis KK, Kasimis JC, Lopez DS, Ntzani EE, Ioannidis JP. Type 2 diabetes and cancer: umbrella review of meta-analyses of observational studies. BMJ 2015;350:g7607.

11. Shlomai G, Neel B, LeRoith D, Gallagher EJ. Type 2 diabetes mellitus and cancer: the role of pharmacotherapy. J Clin Oncol 2016;34:4261-9.

12. Wu L, Zhu J, Prokop LJ, Murad MH. Pharmacologic therapy of diabetes and overall cancer risk and mortality: a meta-analysis of 265 studies. Sci Rep 2015;5:10147.

13. Suh S, Kim KW. Diabetes and cancer: is diabetes causally related to cancer? Diabetes Metab J 2011;35:193-8.

14. Cignarelli A, Genchi VA, Caruso I, Natalicchio A, Perrini S, Laviola L, Giorgino F. Diabetes and cancer: pathophysiological fundamentals of a 'dangerous affair'. Diabetes Res Clin Pract 2018;143:378-88.

15. Noto H, Tsujimoto T, Noda M. Significantly increased risk of cancer in diabetes mellitus patients: a meta-analysis of epidemiological evidence in Asians and non-Asians. J Diabetes Investig 2012;3:24-33.

16. Carstensen B, Read SH, Friis S, Sund R, Keskimaki I, Svensson AM, Ljung R, Wild SH, Kerssens JJ, Harding JL, Magliano DJ, Gudbjornsdottir S; Diabetes and Cancer Research Consortium. Cancer incidence in persons with type 1 diabetes: a fivecountry study of 9,000 cancers in type 1 diabetic individuals. Diabetologia 2016;59:980-8.

17. Huang Y, Cai X, Qiu M, Chen P, Tang H, Hu Y, Huang Y. Prediabetes and the risk of cancer: a meta-analysis. Diabetologia 2014;57:2261-9.

18. Coughlin SS, Calle EE, Teras LR, Petrelli J, Thun MJ. Diabetes mellitus as a predictor of cancer mortality in a large cohort of US adults. Am J Epidemiol 2004;159:1160-7.

19. Tancredi M, Rosengren A, Svensson AM, Kosiborod M, Piv- odic A, Gudbjornsdottir S, Wedel H, Clements M, Dahlqvist S, Lind M. Excess mortality among persons with type 2 diabetes. N Engl J Med 2015;373:1720-32.

20. Kim KJ, Kwon TY, Yu S, Seo JA, Kim NH, Choi KM, Baik SH, Choi DS, Kim SG, Park Y, Kim NH. Ten-year mortality trends for adults with and without diabetes mellitus in South Korea, 2003 to 2013. Diabetes Metab J 2018;42:394-401.

21. Renehan AG, Yeh HC, Johnson JA, Wild SH, Gale EA, Moller $\mathrm{H}$; Diabetes and Cancer Research Consortium. Diabetes and cancer (2): evaluating the impact of diabetes on mortality in patients with cancer. Diabetologia 2012;55:1619-32.

22. Li S, Wang J, Zhang B, Li X, Liu Y. Diabetes mellitus and causespecific mortality: a population-based study. Diabetes Metab J 2019;43:319-41.

23. Barone BB, Yeh HC, Snyder CF, Peairs KS, Stein KB, Derr RL, Wolff AC, Brancati FL. Long-term all-cause mortality in cancer patients with preexisting diabetes mellitus: a systematic review and meta-analysis. JAMA 2008;300:2754-64.

24. Chen Y, Wu F, Saito E, Lin Y, Song M, Luu HN, Gupta PC, Sawada N, Tamakoshi A, Shu XO, Koh WP, Xiang YB, Tomata Y, Sugiyama K, Park SK, Matsuo K, Nagata C, Sugawara Y, Qiao YL, You SL, Wang R, Shin MH, Pan WH, Pednekar MS, Tsugane S, Cai H, Yuan JM, Gao YT, Tsuji I, Kanemura S, Ito H, Wada K, Ahn YO, Yoo KY, Ahsan H, Chia KS, Boffetta P, Zheng W, Inoue M, Kang D, Potter JD. Association between type 2 diabetes and risk of cancer mortality: a pooled analysis of over 771,000 individuals in the Asia Cohort Consortium. Diabetologia 2017;60:1022-32.

25. Harding JL, Shaw JE, Peeters A, Cartensen B, Magliano DJ. Cancer risk among people with type 1 and type 2 diabetes: disentangling true associations, detection bias, and reverse causation. Diabetes Care 2015;38:264-70.

26. van de Poll-Franse LV, Houterman S, Janssen-Heijnen ML, Dercksen MW, Coebergh JW, Haak HR. Less aggressive treatment and worse overall survival in cancer patients with diabetes: a large population based analysis. Int J Cancer 2007;120: 1986-92.

27. Ko C, Chaudhry S. The need for a multidisciplinary approach to cancer care. J Surg Res 2002;105:53-7.

28. Giovannucci E, Harlan DM, Archer MC, Bergenstal RM, Gapstur SM, Habel LA, Pollak M, Regensteiner JG, Yee D. Diabetes and cancer: a consensus report. Diabetes Care 2010;33:167485.

29. Pearson-Stuttard J, Zhou B, Kontis V, Bentham J, Gunter MJ, Ezzati M. Worldwide burden of cancer attributable to diabetes 
and high body-mass index: a comparative risk assessment. Lancet Diabetes Endocrinol 2018;6:e6-15.

30. Lim SS, Vos T, Flaxman AD, Danaei G, Shibuya K, Adair-Rohani H, Amann M, Anderson HR, Andrews KG, Aryee M, Atkinson C, Bacchus LJ, Bahalim AN, Balakrishnan K, Balmes J, Barker-Collo S, Baxter A, Bell ML, Blore JD, Blyth F, Bonner C, Borges G, Bourne R, Boussinesq M, Brauer M, Brooks P, Bruce NG, Brunekreef B, Bryan-Hancock C, Bucello C, Buchbinder R, Bull F, Burnett RT, Byers TE, Calabria B, Carapetis J, Carnahan E, Chafe Z, Charlson F, Chen H, Chen JS, Cheng AT, Child JC, Cohen A, Colson KE, Cowie BC, Darby S, Darling S, Davis A, Degenhardt L, Dentener F, Des Jarlais DC, Devries K, Dherani M, Ding EL, Dorsey ER, Driscoll T, Edmond K, Ali SE, Engell RE, Erwin PJ, Fahimi S, Falder G, Farzadfar F, Ferrari A, Finucane MM, Flaxman S, Fowkes FG, Freedman G, Freeman MK, Gakidou E, Ghosh S, Giovannucci E, Gmel G, Graham K, Grainger R, Grant B, Gunnell D, Gutierrez HR, Hall W, Hoek HW, Hogan A, Hosgood HD 3rd, Hoy D, Hu H, Hubbell BJ, Hutchings SJ, Ibeanusi SE, Jacklyn GL, Jasrasaria R, Jonas JB, Kan H, Kanis JA, Kassebaum N, Kawakami N, Khang YH, Khatibzadeh S, Khoo JP, Kok C, Laden F, Lalloo R, Lan Q, Lathlean T, Leasher JL, Leigh J, Li Y, Lin JK, Lipshultz SE, London S, Lozano R, Lu Y, Mak J, Malekzadeh R, Mallinger L, Marcenes W, March L, Marks R, Martin R, McGale P, McGrath J, Mehta S, Mensah GA, Merriman TR, Micha R, Michaud C, Mishra V, Mohd Hanafiah K, Mokdad AA, Morawska L, Mozaffarian D, Murphy T, Naghavi M, Neal B, Nelson PK, Nolla JM, Norman R, Olives C, Omer SB, Orchard J, Osborne R, Ostro B, Page A, Pandey KD, Parry CD, Passmore E, Patra J, Pearce N, Pelizzari PM, Petzold M, Phillips MR, Pope D, Pope CA 3rd, Powles J, Rao M, Razavi H, Rehfuess EA, Rehm JT, Ritz B, Rivara FP, Roberts T, Robinson C, Rodriguez-Portales JA, Romieu I, Room R, Rosenfeld LC, Roy A, Rushton L, Salomon JA, Sampson U, Sanchez-Riera L, Sanman E, Sapkota A, Seedat S, Shi P, Shield K, Shivakoti R, Singh GM, Sleet DA, Smith E, Smith KR, Stapelberg NJ, Steenland K, Stockl H, Stovner LJ, Straif K, Straney L, Thurston GD, Tran JH, Van Dingenen R, van Donkelaar A, Veerman JL, Vijayakumar L, Weintraub R, Weissman MM, White RA, Whiteford H, Wiersma ST, Wilkinson JD, Williams HC, Williams W, Wilson N, Woolf AD, Yip P, Zielinski JM, Lopez AD, Murray CJ, Ezzati M, AlMazroa MA, Memish ZA. A comparative risk assessment of burden of disease and injury attributable to 67 risk factors and risk factor clusters in 21 regions, 1990-2010: a systematic analysis for the Global Burden of Disease Study 2010. Lancet
2012;380:2224-60

31. Noto H. Unfolding link between diabetes and cancer. J Diabetes Investig 2018;9:473-4.

32. Ryu TY, Park J, Scherer PE. Hyperglycemia as a risk factor for cancer progression. Diabetes Metab J 2014;38:330-6.

33. Hua F, Yu JJ, Hu ZW. Diabetes and cancer, common threads and missing links. Cancer Lett 2016;374:54-61.

34. Barclay AW, Petocz P, McMillan-Price J, Flood VM, Prvan T, Mitchell P, Brand-Miller JC. Glycemic index, glycemic load, and chronic disease risk: a meta-analysis of observational studies. Am J Clin Nutr 2008;87:627-37.

35. Kang YM, Kim F, Lee WJ. Role of NO/VASP signaling pathway against obesity-related inflammation and insulin resistance. Diabetes Metab J 2017;41:89-95.

36. Anothaisintawee T, Wiratkapun C, Lerdsitthichai P, Kasamesup V, Wongwaisayawan S, Srinakarin J, Hirunpat S, Woodtichartpreecha P, Boonlikit S, Teerawattananon Y, Thakkinstian A. Risk factors of breast cancer: a systematic review and metaanalysis. Asia Pac J Public Health 2013;25:368-87.

37. Calle EE, Kaaks R. Overweight, obesity and cancer: epidemiological evidence and proposed mechanisms. Nat Rev Cancer 2004;4:579-91.

38. Ricart W, Fernandez-Real JM. No decrease in free IGF-I with increasing insulin in obesity-related insulin resistance. Obes Res 2001;9:631-6.

39. Terzolo M, Reimondo G, Berchialla P, Ferrante E, Malchiodi E, De Marinis L, Pivonello R, Grottoli S, Losa M, Cannavo S, Ferone D, Montini M, Bondanelli M, De Menis E, Martini C, Puxeddu E, Velardo A, Peri A, Faustini-Fustini M, Tita P, Pigliaru F, Peraga G, Borretta G, Scaroni C, Bazzoni N, Bianchi A, Berton A, Serban AL, Baldelli R, Fatti LM, Colao A, Arosio M; Italian Study Group of Acromegaly. Acromegaly is associated with increased cancer risk: a survey in Italy. Endocr Relat Cancer 2017;24:495-504.

40. Kyrgiou M, Kalliala I, Markozannes G, Gunter MJ, Paraskevaidis E, Gabra H, Martin-Hirsch P, Tsilidis KK. Adiposity and cancer at major anatomical sites: umbrella review of the literature. BMJ 2017;356:j477.

41. Byers T, Sedjo RL. Body fatness as a cause of cancer: epidemiologic clues to biologic mechanisms. Endocr Relat Cancer 2015; 22:R125-34.

42. Arnold M, Pandeya N, Byrnes G, Renehan PAG, Stevens GA, Ezzati PM, Ferlay J, Miranda JJ, Romieu I, Dikshit R, Forman D, Soerjomataram I. Global burden of cancer attributable to high body-mass index in 2012: a population-based study. Lan- 
cet Oncol 2015;16:36-46.

43. Xu J, Ye Y, Wu H, Duerksen-Hughes P, Zhang H, Li P, Huang J, Yang J, Wu Y, Xia D. Association between markers of glucose metabolism and risk of colorectal cancer. BMJ Open 2016;6: e011430.

44. Yu F, Guo Y, Wang H, Feng J, Jin Z, Chen Q, Liu Y, He J. Type 2 diabetes mellitus and risk of colorectal adenoma: a meta-analysis of observational studies. BMC Cancer 2016;16:642.

45. Suh S, Kang M, Kim MY, Chung HS, Kim SK, Hur KY, Kim JH, Lee MS, Lee MK, Kim KW. Korean type 2 diabetes patients have multiple adenomatous polyps compared to non-diabetic controls. J Korean Med Sci 2011;26:1196-200.

46. Tang H, Dai Q, Shi W, Zhai S, Song Y, Han J. SGLT2 inhibitors and risk of cancer in type 2 diabetes: a systematic review and meta-analysis of randomized controlled trials. Diabetologia 2017;60:1862-72.

47. Ptaszynska A, Cohen SM, Messing EM, Reilly TP, Johnsson E, Johnsson K. Assessing bladder cancer risk in type 2 diabetes clinical trials: the dapagliflozin drug development program as a 'case study'. Diabetes Ther 2015;6:357-75.

48. Overbeek JA, Bakker M, van der Heijden AAWA, van HerkSukel MPP, Herings RMC, Nijpels G. Risk of dipeptidyl peptidase-4 (DPP-4) inhibitors on site-specific cancer: a systematic review and meta-analysis. Diabetes Metab Res Rev 2018;34: e3004.

49. Romera I, Cebrian-Cuenca A, Alvarez-Guisasola F, GomezPeralta F, Reviriego J. A review of practical issues on the use of glucagon-like peptide-1 receptor agonists for the management of type 2 diabetes. Diabetes Ther 2019;10:5-19.

50. Monami M, Nreu B, Scatena A, Cresci B, Andreozzi F, Sesti G, Mannucci E. Safety issues with glucagon-like peptide-1 receptor agonists (pancreatitis, pancreatic cancer and cholelithiasis): data from randomized controlled trials. Diabetes Obes Metab 2017;19:1233-41.

51. Pinto LC, Rados DV, Barkan SS, Leitao CB, Gross JL. Dipeptidyl peptidase- 4 inhibitors, pancreatic cancer and acute pancreatitis: a meta-analysis with trial sequential analysis. Sci Rep 2018;8:782.

52. Zhang Z, Chen X, Lu P, Zhang J, Xu Y, He W, Li M, Zhang S, Jia J, Shao S, Xie J, Yang Y, Yu X. Incretin-based agents in type 2 diabetic patients at cardiovascular risk: compare the effect of GLP-1 agonists and DPP-4 inhibitors on cardiovascular and pancreatic outcomes. Cardiovasc Diabetol 2017;16:31.

53. Tseng CH, Lee KY, Tseng FH. An updated review on cancer risk associated with incretin mimetics and enhancers. J Envi- ron Sci Health C Environ Carcinog Ecotoxicol Rev 2015;33:67124.

54. American Diabetes Association. 9. Pharmacologic approaches to glycemic treatment: standards of medical care in diabetes. 2019. Diabetes Care 2019;42(Suppl 1):S90-102.

55. Monami M, Dicembrini I, Mannucci E. Thiazolidinediones and cancer: results of a meta-analysis of randomized clinical trials. Acta Diabetol 2014;51:91-101.

56. Kulke MH, Demetri GD, Sharpless NE, Ryan DP, Shivdasani R, Clark JS, Spiegelman BM, Kim H, Mayer RJ, Fuchs CS. A phase II study of troglitazone, an activator of the PPARgamma receptor, in patients with chemotherapy-resistant metastatic colorectal cancer. Cancer J 2002;8:395-9.

57. Burstein HJ, Demetri GD, Mueller E, Sarraf P, Spiegelman BM, Winer EP. Use of the peroxisome proliferator-activated receptor (PPAR) gamma ligand troglitazone as treatment for refractory breast cancer: a phase II study. Breast Cancer Res Treat 2003;79: 391-7.

58. Yee LD, Williams N, Wen P, Young DC, Lester J, Johnson MV, Farrar WB, Walker MJ, Povoski SP, Suster S, Eng C. Pilot study of rosiglitazone therapy in women with breast cancer: effects of short-term therapy on tumor tissue and serum markers. Clin Cancer Res 2007;13:246-52.

59. Dormandy JA, Charbonnel B, Eckland DJ, Erdmann E, MassiBenedetti M, Moules IK, Skene AM, Tan MH, Lefèbvre PJ, Murray GD, Standl E, Wilcox RG, Wilhelmsen L, Betteridge J, Birkeland K, Golay A, Heine RJ, Koranyi L, Laakso M, Mokan M, Norkus A, Pirags V, Podar T, Scheen A, Scherbaum W, Schernthaner G, Schmitz O, Skrha J, Smith U, Taton J; PROactive Investigators. Secondary prevention of macrovascular events in patients with type 2 diabetes in the PROactive Study (PROspective pioglitAzone Clinical Trial In macroVascular Events): a randomized controlled trial. Lancet 2005;366:127989.

60. Ryder RE. Pioglitazone has a dubious bladder cancer risk but an undoubted cardiovascular benefit. Diabet Med 2015;32:305-13.

61. Jin SM, Song SO, Jung CH, Chang JS, Suh S, Kang SM, Jung I, Park CY, Kim JH, Cho JH, Lee BW. Risk of bladder cancer among patients with diabetes treated with a $15 \mathrm{mg}$ pioglitazone dose in Korea: a multi-center retrospective cohort study. J Korean Med Sci 2014;29:238-42.

62. Lewis JD, Habel LA, Quesenberry CP, Strom BL, Peng T, Hedderson MM, Ehrlich SF, Mamtani R, Bilker W, Vaughn DJ, Nessel L, Van Den Eeden SK, Ferrara A. Pioglitazone use and risk of bladder cancer and other common cancers in persons 
with diabetes. JAMA 2015;314:265-77.

63. Mehtälä J, Khanfir H, Bennett D, Ye Y, Korhonen P, Hoti F. Pioglitazone use and risk of bladder cancer: a systematic literature review and meta-analysis of observational studies. Diabetol Int 2018;10:24-36.

64. Badrick E, Renehan AG. Diabetes and cancer: 5 years into the recent controversy. Eur J Cancer 2014;50:2119-25.

65. Thakkar B, Aronis KN, Vamvini MT, Shields K, Mantzoros CS. Metformin and sulfonylureas in relation to cancer risk in type II diabetes patients: a meta-analysis using primary data of published studies. Metabolism 2013;62:922-34.

66. Chen L, Chubak J, Boudreau DM, Barlow WE, Weiss NS, Li CI. Diabetes treatments and risks of adverse breast cancer outcomes among early-stage breast cancer patients: a SEER-medicare analysis. Cancer Res 2017;77:6033-41.

67. Pasello G, Urso L, Conte P, Favaretto A. Effects of sulfonylureas on tumor growth: a review of the literature. Oncologist 2013; 18:1118-25.

68. Gandini S, Puntoni M, Heckman-Stoddard BM, Dunn BK, Ford L, DeCensi A, Szabo E. Metformin and cancer risk and mortality: a systematic review and meta-analysis taking into account biases and confounders. Cancer Prev Res (Phila) 2014; 7:867-85.

69. Heckman-Stoddard BM, DeCensi A, Sahasrabuddhe VV, Ford LG. Repurposing metformin for the prevention of cancer and cancer recurrence. Diabetologia 2017;60:1639-47.

70. Liu X, Chhipa RR, Pooya S, Wortman M, Yachyshin S, Chow LM, Kumar A, Zhou X, Sun Y, Quinn B, McPherson C, Warnick RE, Kendler A, Giri S, Poels J, Norga K, Viollet B, Grabowski GA, Dasgupta B. Discrete mechanisms of mTOR and cell cycle regulation by AMPK agonists independent of AMPK. Proc Natl Acad Sci U S A 2014;111:E435-44.

71. Pollak M. Overcoming drug development bottlenecks with repurposing: repurposing biguanides to target energy metabolism for cancer treatment. Nat Med 2014;20:591-3.

72. Sciacca L, Cassarino MF, Genua M, Pandini G, Le Moli R, Squatrito S, Vigneri R. Insulin analogues differently activate insulin receptor isoforms and post-receptor signalling. Diabetologia 2010;53:1743-53.

73. Renehan AG. Insulin analogues and cancer risk: the emergence of second-generation studies. Diabetologia 2012;55:7-9.

74. ORIGIN Trial Investigators, Gerstein HC, Bosch J, Dagenais GR, Diaz R, Jung H, Maggioni AP, Pogue J, Probstfield J, Ramachandran A, Riddle MC, Ryden LE, Yusuf S. Basal insulin and cardiovascular and other outcomes in dysglycemia. N Engl J Med 2012;367:319-28.

75. ORIGIN Trial Investigators. Cardiovascular and other outcomes postintervention with insulin glargine and omega-3 fatty acids (ORIGINALE). Diabetes Care 2016;39:709-16.

76. Starup-Linde J, Karlstad O, Eriksen SA, Vestergaard P, Bronsveld HK, de Vries F, Andersen M, Auvinen A, Haukka J, Hjellvik V, Bazelier MT, Boer Ad, Furu K, De Bruin ML. CARING (CAncer Risk and INsulin analoGues): the association of diabetes mellitus and cancer risk with focus on possible determinants. A systematic review and a meta-analysis. Curr Drug Saf 2013;8:296-332.

77. Sommerfeld MR, Muller G, Tschank G, Seipke G, Habermann $\mathrm{P}$, Kurrle R, Tennagels N. In vitro metabolic and mitogenic signaling of insulin glargine and its metabolites. PLoS One 2010;5: e9540.

78. American Diabetes Association. 4. Comprehensive medical evaluation and assessment of comorbidities: standards of medical care in diabetes. 2019. Diabetes Care 2019;42(Suppl 1):S3445.

79. Lee JH, Kim SA, Park HY, Lee KH, Lee KT, Lee JK, Bae JC, Kim KW. New-onset diabetes patients need pancreatic cancer screening? J Clin Gastroenterol 2012;46:e58-61.

80. Suh M, Choi KS, Park B, Lee YY, Jun JK, Lee DH, Kim Y. Trends in cancer screening rates among Korean men and women: results of the Korean National Cancer Screening Survey, 2004-2013. Cancer Res Treat 2016;48:1-10.

81. Chuck KW, Hwang M, Choi KS, Suh M, Jun JK, Park B. Cancer screening rate in people with diabetes in the Korean population: results from the Korea National Health and Nutrition Examination Survey 2007-2009. Epidemiol Health 2017;39:e2017036.

82. Lipscombe LL, Hux JE, Booth GL. Reduced screening mammography among women with diabetes. Arch Intern Med 2005;165:2090-5.

83. McBean AM, Yu X. The underuse of screening services among elderly women with diabetes. Diabetes Care 2007;30:1466-72. 